Available online at www.sciencedirect.com

SCIENCE

Forest Ecology and Management 185 (2003) 327-340
Forest Ecology and

Management

www.elsevier.com/locate/foreco

\title{
Association between severity of prescribed burns and subsequent activity of conifer-infesting beetles in stands of longleaf pine
}

\author{
Brian T. Sullivan ${ }^{\mathrm{a}, *}$, Christopher J. Fettig ${ }^{\mathrm{b}}$, William J. Otrosina ${ }^{\mathrm{c}}$, \\ Mark J. Dalusky ${ }^{\mathrm{d}}$, C. Wayne Berisford ${ }^{\mathrm{d}}$ \\ ${ }^{a}$ Southern Research Station, USDA Forest Service, 2500 Shreveport Highway, Pineville, LA 71360, USA \\ ${ }^{\mathrm{b}}$ Pacific Southwest Research Station, USDA Forest Service, 1107 Kennedy Place, Suite 8, Davis, CA 95616, USA \\ ${ }^{\mathrm{c}}$ Southern Research Station, USDA Forest Service, 320 Green Street, Athens, GA 30602, USA \\ ${ }^{\mathrm{d}}$ Department of Entomology, University of Georgia, Athens, GA 30602, USA
}

Received 4 February 2003; received in revised form 26 March 2003; accepted 5 May 2003

\begin{abstract}
A randomized complete block experiment was performed to measure the effect of prescribed, dormant-season burns of three different levels of severity (measured as fuel consumption and soil surface heating) on subsequent insect infestation and mortality of mature longleaf pine (Pinus palustris Mill.). Multiple-funnel traps baited with a low release rate of turpentine and ethanol were used to monitor activity of certain coniferophagous beetles. Non-aggressive species, including the root beetles Hylastes salebrosus Eichhoff and H. tenuis Eichhoff, the ambrosia beetle Xyleborus pubescens Zimmermann, the reproduction weevil Pachylobius picivorus (Germar), and buprestid borers, were attracted to burned plots in numbers that correlated positively with burn severity. Beetle attraction to burned sites was greatest in the first weeks post-burn and disappeared by the second year. Two potential tree-killing bark beetles, Dendroctonus terebrans (Olivier) and Ips grandicollis (Eichhoff), were trapped in significant numbers but exhibited no attraction to burned plots. Tree mortality correlated significantly with the severity of the burns and amounted to 5\% of stems in the hottest burn treatment after 3 years. The majority of the mortality was observed in the second and third years post-burn. Attacks of Ips and Dendroctonus bark beetles were apparent on nearly all dead or dying trees, and evidence suggested that root pathogens may have contributed to tree susceptibility to beetle attack and mortality. Our data indicate that selection of burn regimes that reduce or eliminate consumption of duff (e.g., favoring heading fires over backing fires) could significantly reduce mortality of longleaf pine managed for long rotations.
\end{abstract}

Published by Elsevier B.V.

Keywords: Pinus palustris; Buprestidae; Curculionidae; Scolytidae; Prescribed fire; Semiochemicals

\section{Introduction}

Prescribed fire is a forest management tool used to reduce the buildup of hazardous fuels, enhance wildlife

\footnotetext{
* Corresponding author. Tel.: +1-318-473-7206; fax: 1-318-473-7222.

E-mail address: briansullivan@fs.fed.us (B.T. Sullivan).
}

habitat, improve land for grazing, thin overstocked stands, control insects and disease, prepare sites for reforestation, and restore fire-adapted ecosystems (Davis, 1959; Cooper, 1971; Langdon, 1971; Wright and Bailey, 1982; McCullough et al., 1998). However, forest managers must plan and execute prescribed burns carefully in order to minimize injury to desirable tree species while still fulfilling management objectives 
(Davis, 1959). Although a fire's heat can kill critical plant tissues and directly cause tree mortality, fire often merely weakens trees until they become susceptible to lethal attacks by bark beetles and other wood-boring insects (Rasmussen et al., 1996; McCullough et al., 1998; Fernandez and Costas, 1999).

Longleaf pine, Pinus palustris Mill., is native to the coastal plain of the southern United States and requires periodic surface fires for its successful regeneration and maintenance in pure stands (Croker and Boyer, 1975; Burns and Honkala, 1990). In the absence of fire, longleaf pine is replaced with less fire-adapted species such as loblolly (P. taeda L.) and shortleaf (P. echinata Mill.) pine as well as various hardwoods (Bruce, 1947; Haywood et al., 2001). In pre-settlement times, pure stands of old-growth longleaf pine covered a large portion of southern coastal plain, and the decline in the abundance of this species has been attributed, in part, to fire suppression (Noss, 1989; Barnett, 1992). Efforts are currently underway to restore longleaf pine to portions of its original range, and prescribed burning is playing an essential role in these restoration projects (Johnson and Gjerstad, 1998; Horton, 1998; Barnett, 1999).

Through the mid-1990s, forest managers at the Savannah River Site National Environmental Research Park experienced unacceptable levels of mortality in second growth stands of thinned longleaf pine following prescribed burns. Mortality was largely attributed to post-burn attacks by bark beetles, especially the black turpentine beetle, Dendroctonus terebrans (Olivier). The rate of tree loss was incompatible with the long rotations required for producing foraging and nesting habitat for the endangered red-cockaded woodpecker (RCW), Picoides borealis. At that time, the preferred fire regime for RCW habitat and other environmentally sensitive stands involved low-intensity backing fires. These were presumed to minimize tree mortality by reducing flame height and thereby lessening damage to crowns (Fahnestock and Hare, 1964; Cooper, 1971, 1975). However, stands suffered high mortality despite having minimal crown damage. Greater post-fire mortality was observed in stands with large accumulations of litter and duff, suggesting that tree losses were more closely associated with the depth of surface fuels consumed by fire than flame height. The purpose of our study was to identify burn regimes that might offer acceptable levels of overstory tree mortality while still realizing the beneficial effects of prescribed fire. We were especially interested in understanding the role that bark- and root-infesting beetles might play in burnassociated mortality of longleaf pine, and we wished to determine whether prescribed fire might directly influence beetle abundance and behavior.

\section{Materials and methods}

In the fall of 1996, sixteen 2 ha square experimental plots were established in old-field, planted stands of longleaf pine located in the Savannah River Site National Environmental Research Park, Barnwell County, South Carolina. The stands were 35-42 years old, and had been thinned in the previous 2 years to a basal area of approximately $18 \mathrm{~m}^{2} / \mathrm{h}$. The stands had undergone periodic prescribed burning since their establishment, but had not been burned in the previous 5 years. The soil was a mixture of Blanton (Grossarenic Paleudults) and Fuquay (Arenic plinthic Kandiudults), and the terrain was flat or gently rolling. Available fuels consisted almost entirely of pine litter and underlying duff (i.e., partially decomposed organic material above the mineral soil), cones, and small branches.

Plots were arranged in a randomized complete block design with four complete blocks each confined within the boundaries of a single, uniformly managed stand. Each block consisted of four adjacent plots assigned randomly to one of four treatments. Three of the four plots within each block were burned to produce low, medium, or high levels of fire severity, and the fourth plot was left unburned as a control (Table 1). Burn severity was regulated by setting either headfires or backfires and by executing the burns during varying conditions of fuel moisture, humidity, and air temperature. Fire lines consisting of $\sim 1.5 \mathrm{~m}$ wide strips of exposed mineral soil were established with a plow around the perimeters of all plots. Fires were ignited with drip torches along one edge of each plot and allowed to burn without intervention to the opposite edge. Burns were conducted between 12 February and 9 March 1997 during daylight hours.

\subsection{Burn measurements}

Prior to burning, five high-registering mercury thermometers were buried in each plot to provide an 
Table 1

Parameters of three prescribed burn treatments applied to 2 ha plots of longleaf pine, P. palustris Mill., in Barnwell Co., SC, during the winter of 1997

\begin{tabular}{|c|c|c|c|}
\hline Variable & Low severity & Medium severity & High severity \\
\hline \multicolumn{4}{|l|}{ Burn parameters } \\
\hline Fire direction & Heading & Heading & Backing \\
\hline \multicolumn{4}{|l|}{ Climatic conditions during burns } \\
\hline Air temperature $\left({ }^{\circ} \mathrm{F}\right)$ & $52-60$ & $60-75$ & $66-82$ \\
\hline Relative humidity (\%) & $30-58$ & $36-59$ & $25-55$ \\
\hline Fuel moisture $(\%)^{\mathrm{a}}$ & $16.0-19.0$ & $9.0-15.0$ & $10.3-14.1$ \\
\hline Wind speed (mph) & $1-5$ & $0-4$ & $0-7$ \\
\hline Days since rain ${ }^{\mathrm{b}}$ & $2-3$ & $5-6$ & $8-9$ \\
\hline $\mathrm{KBDI}^{\mathrm{c}}$ & $6-20$ & $17-26$ & $113-123$ \\
\hline \multicolumn{4}{|l|}{ Fire effects (mean \pm S.E. $)^{\mathrm{d}}$} \\
\hline Maximum temperature at soil surface $\left({ }^{\circ} \mathrm{C}\right)^{\mathrm{e}}$ & $28.9 \pm 2.4 \mathrm{a}$ & $36.1 \pm 2.0 \mathrm{~b}$ & $60.3 \pm 2.1 \mathrm{c}$ \\
\hline Total fuel consumed $\left(\mathrm{g} / \mathrm{m}^{2}\right)^{\mathrm{f}}$ & $453.8 \pm 84.3 \mathrm{a}$ & $572.0 \pm 77.4 \mathrm{a}$ & $1068.8 \pm 82.2 \mathrm{~b}$ \\
\hline Litter consumed $\left(\mathrm{g} / \mathrm{m}^{2}\right)$ & $416.0 \pm 54.5$ & $426.4 \pm 11.6$ & $469.6 \pm 35.8$ \\
\hline Duff consumed $\left(\mathrm{g} / \mathrm{m}^{2}\right)$ & $38.8 \pm 54.4 \mathrm{a}$ & $149.0 \pm 40.5 \mathrm{a}$ & $404.5 \pm 67.2 \mathrm{~b}$ \\
\hline Trees with $>75 \%$ crown scorch & $0.25 \pm 0.25$ & $10.0 \pm 10.0$ & $9.0 \pm 5.2$ \\
\hline
\end{tabular}

estimate of peak soil surface temperature. One thermometer was located at plot center and the others placed $64 \mathrm{~m}$ from plot center in line with the plot's four corners. The thermometers were enclosed in protective metal casings and inserted horizontally along the interface between the mineral soil and overlying organic layers.

The dry weight of fuel consumed was used as a relative measure of heat energy released by the fires (Wade and Johansen, 1986) and fire severity. Fuel sampling methods are explained in detail elsewhere (Scholl and Waldrop, 1999). Sixteen subplots $\left(1 \mathrm{~m}^{2}\right)$ in each treatment plot were divided into four equal quadrants, and two opposing quadrants were destructively sampled both before and after burning. Litter, duff, and other surface fuels (all live and dead organic material $<2.5 \mathrm{~cm}$ diameter and $<1 \mathrm{~m}$ above the mineral soil) were collected separately, dried at $90{ }^{\circ} \mathrm{C}$ for $2-3$ days, and weighed. Fuel consumption was calculated by subtracting the weights of the pre-burn quadrants from those of the post-burn quadrants for each subplot. Consumption of woody fuels $>2.5 \mathrm{~cm}$ diameter was not estimated. Trees that had more than $75 \%$ of their crown volume scorched were recorded.

\subsection{Site monitoring}

A $100 \%$ cruise was conducted in all plots 1 month prior to burn treatments and then twice annually for the next 3 years. Every pine $>10 \mathrm{~cm}$ DBH was inspected for evidence of beetle attacks on the bole. Fading and dead trees were permanently marked, and the maximum height of bole char, the extent of insect damage, and the taxa of attacking insects were recorded. Attacking insects were usually identified by the presence of mines, frass, pitch tubes, and other damage characteristic of particular taxa (Baker, 1972; Wood, 1982).

\subsection{Trapping experiments}

Within 3 days after completion of burn treatments, four 12-unit Lindgren funnel traps (PheroTech Inc., Burnaby, BC, Canada) were erected in each plot to 
monitor activity of conifer-infesting beetles. Traps were positioned $30 \mathrm{~m}$ from plot center and arranged in a square. All traps were suspended $>2 \mathrm{~m}$ from the nearest tree and with the trap bottom 5-20 cm above the ground. Trap baits consisted of a capped $60 \mathrm{ml}$ Nalgene $^{\mathrm{TM}}$ narrow-mouth HDPE bottle with $30 \mathrm{ml}$ turpentine (Sunnyside ${ }^{\mathrm{TM}}$ gum spirits of turpentine, Wheeling, Ill.) and a $7 \mathrm{~cm} \times 8 \mathrm{~cm}$ sealed LDPE bag with $10-15 \mathrm{ml} 95 \%$ ethanol. Turpentine and ethanol are attractive to a diversity of conifer-infesting beetles, including D. terebrans (Phillips et al., 1988; Chenier and Philogene, 1989). Both bait containers released their contents at a rate of $20 \pm 6 \mathrm{mg}$ per day when suspended in a fume hood at $23 \pm 3{ }^{\circ} \mathrm{C}$. This relatively low release rate reduced the risk of attracting insects from outside the plots while generally assuring catch numbers adequate for statistical analyses. In each trap, the baits were suspended adjacent to one another inside the fourth-lowest funnel.

A 3:1 mixture of water and propylene glycol in the trap collection cups slowed the decomposition of trapped insects. Catch was retrieved approximately biweekly in spring and summer and monthly in late fall and winter. Insects were preserved in $70 \%$ ethanol and identified using available keys and reference collections (Wood, 1982; Borror et al., 1989). Voucher specimens were deposited with the Natural History Museum of the University of Georgia, Athens, GA.

\subsection{Statistical analyses}

Mean values for each plot were calculated for fuel consumption, temperature, and trap catch. Statistical analyses were conducted using a 2-way analysis of variance (ANOVA) with burn treatment and block as the two factors (SPSS, 1997). All-pairwise comparisons were performed with the Student-NewmanKeuls (SNK) procedure $(\alpha=0.05)$. Trap catches during the first (13 March-30 September 1997) and second (9 March-24 September 1998) years following the burns were pooled and analyzed separately. Trap catch data were transformed with the formula $\log _{10}(X+$ a constant). Correlations between trap catch and fuel consumption within each plot $(n=16)$ were identified with Spearman's rank order correlation, and the relationship between soil temperature, tree mortality, and fuel consumption was analyzed with linear regression (SPSS, 1997).

\section{Results}

The three different burn regimes resulted in significantly different amounts of fuel consumption $\left(F_{2,6}=15.2, P=0.004\right)$ and heating to the ground surface $\left(F_{2,6}=64.7, P<0.001\right)$. Maximum temperatures registered at the soil-duff interface in the high severity burns were significantly higher than those in either the low or medium severity burn treatments $(P<0.001$, Table 1$)$, and maximum temperatures in the medium severity burn plots were higher than those in the low severity burns $(P=0.022)$. Maximum soil temperature showed a strong positive correlation with fuel consumption (Fig. 1a). Significantly greater amounts of fuel were consumed in the high severity burn plots than in either the low or medium severity burn treatments $(P=0.005$ and 0.006 , respectively, Table 1), which did not differ from one another $(P=0.36)$. Consumption of the duff layer in the high severity burns was 3-10 times greater than in the other two treatments $\left(F_{2,6}=8.49, P=0.018\right)$, and duff accounted for most of the additional fuel consumed in the high severity burns (Table 1). Forest litter was largely or completely consumed in all burned plots regardless of treatment severity, hence litter consumption did not differ significantly among the burns $\left(F_{2,6}=0.90, P=0.454\right)$.

In general, visible evidence of fire damage to the trees was light. Relatively little crown scorch occurred, and 71 of 77 trees with greater than $75 \%$ crown scorch were still alive at the end of the 3-year study. Mean height of bole char on trees that subsequently died in the burn plots was $1.9 \mathrm{~m}($ S.E. $=0.13)$, and only seven of these trees $(5 \%)$ had bole char above $5 \mathrm{~m}$.

Mortality was observed predominantly during the second and third years after the burns, and very little occurred in the first post-burn growing season (i.e., 1997). The period of greatest mortality occurred between July 1998 and May 1999. During this 10 -month interval, nearly twice as many trees died in the burn treatment plots (74) as had died during the first 16 months following the burns (38). By the second year post-burn and continuing to the end of the study, cumulative tree mortality reflected treatment severity, with the least mortality occurring in the control plots and the highest in the high severity burn plots (Fig. 2). Mortality differences among the treatments were marginally significant $\left(F_{3,9}=3.68, P=0.056\right)$ at the end 

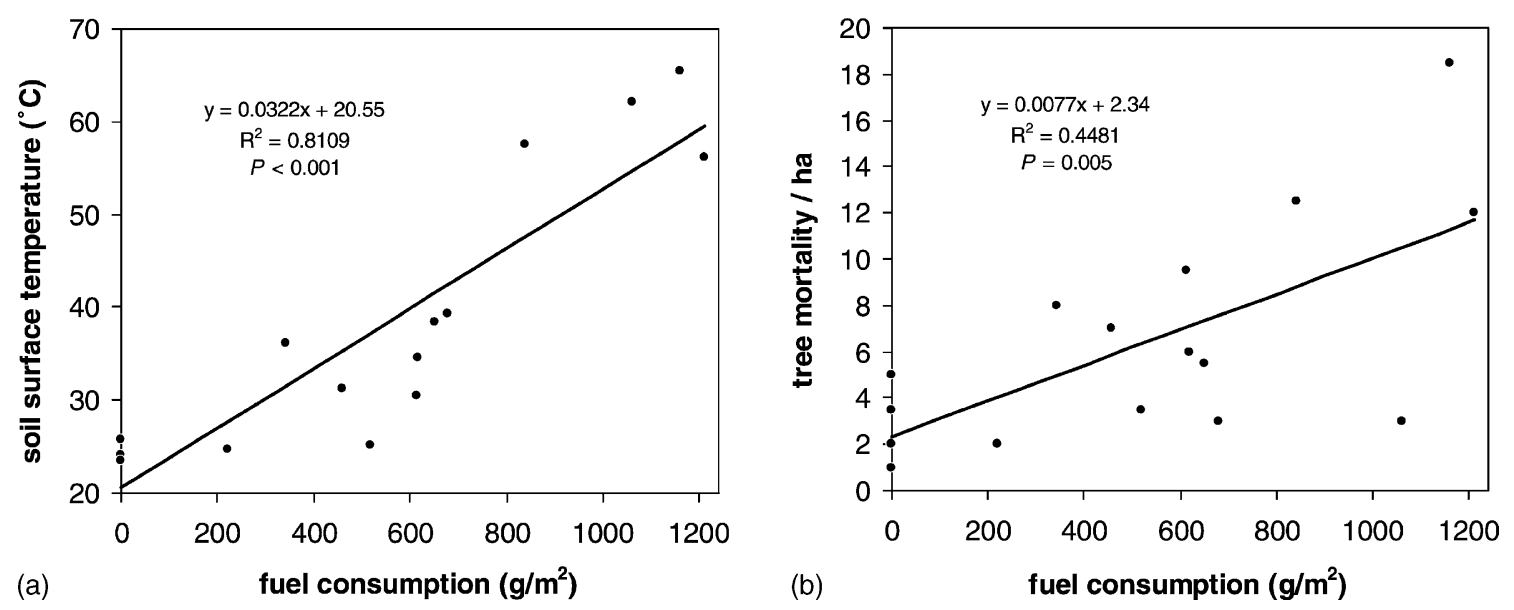

Fig. 1. Linear regressions of maximum soil surface temperatures (a), and accumulated mortality of trees 44 months after the burns (b), regressed against consumption of all fuels $<2 \mathrm{~cm}$ diameter. Data points represent mean measurements from each of sixteen 2 ha study plots.

of the study, with approximately 5\% of trees in the high severity burn plots and $1 \%$ in unburned plots dying. Tree mortality in individual plots correlated positively with the total weight of fuel consumed (Fig. 1b).

Nearly all trees killed during the study had evidence of bark beetle attacks, with $88 \%$ containing galleries indicative of Ips spp., especially Ips calligraphus (Germar). In addition, evidence of D. terebrans, ambrosia beetles (Scolytidae, Platypodidae), and wood borers (Buprestidae, Cerambycidae) was observed in 50, 76, and $81 \%$, respectively, of dead or dying trees. Attacks by $D$. terebrans also were commonly found on otherwise apparently healthy trees (102 cases). Often these

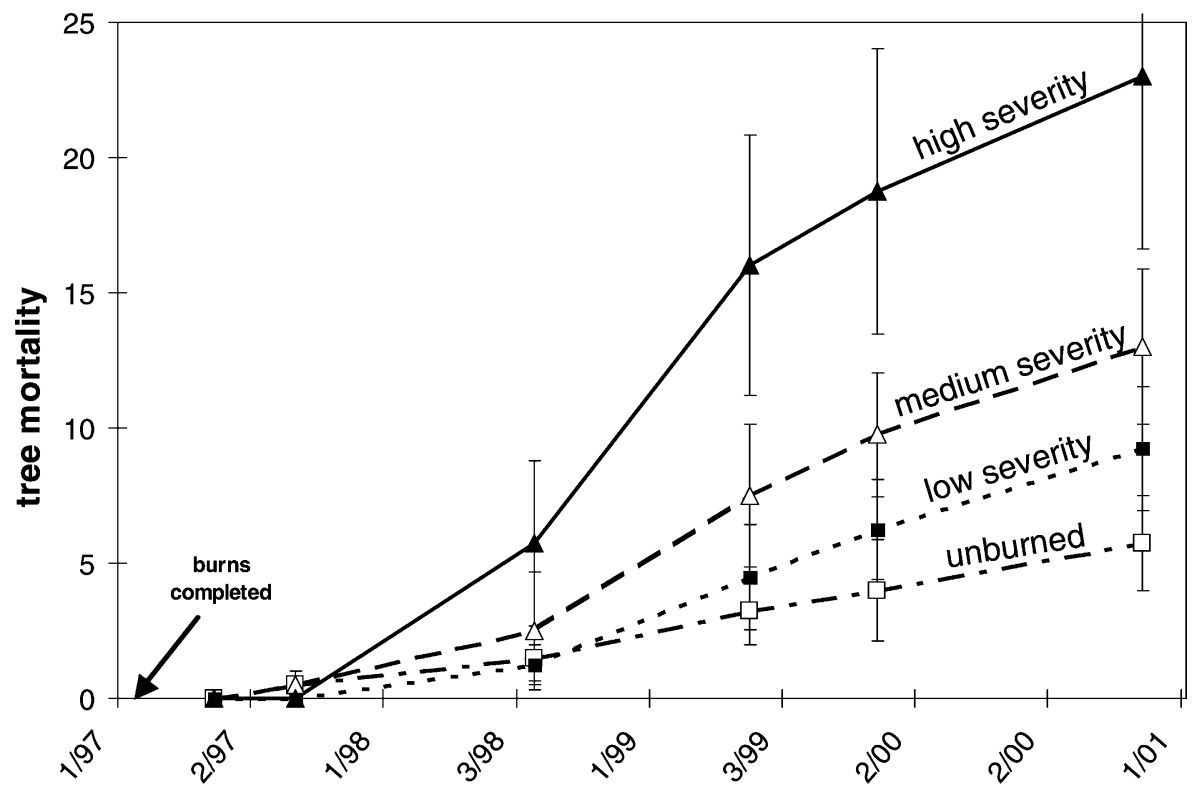

Fig. 2. Cumulative mortality of trees 44 months after burns within 2 ha plots of longleaf pine, P. palustris. Bars show the standard error of the mean. Plots were subjected to prescribed burns of one of the three different levels of severity or were left unburned. 
trees contained ambrosia beetle infestations at or near the root collar. Forty-six percent of green, D. terebransattacked trees died before the end of the study.

Eight taxa (six species and two families) of beetles which infest the roots and stems of pine were trapped in numbers adequate for statistical analyses. These included five species of Scolytidae (D. terebrans, Hylastes salebrosus Eichhoff, H. tenuis Eichoff, Ips grandicollis (Eichhoff), and Xyleborus pubescens Zimmermann), one species of Curculionidae (Pachylobius picivorus (Germar)), and the families Buprestidae and Cerambycidae. Since buprestids and cerambycids were generally not identified to species, a portion of those captured in our traps may have been associated with hardwoods and other non-coniferous hosts. However, the buprestid trapped most frequently was a pine specialist, Chalcophora virginiensis (Drury). Fewer than ten individuals each of three important pine bark beetles native to the region, Ips avulsus (Eichhoff), I. calligraphus (Germar), and D. frontalis Zimmermann, were trapped, hence these were excluded from analyses. The pales weevil, Hylobius pales (Herbst), was also trapped in low numbers.

Trap captures of five beetle taxa increased in response to burning. In the first year post-burn, $X$. pubescens, $H$. salebrosus, $H$. tenuis, $P$. picivorus, and buprestids were trapped in the high and medium severity burns in numbers two to seven times greater than controls (Fig. 3a-e; Table 2). These differences were statistically significant for $X$. pubescens $\left(F_{3,9}=8.41\right.$, $P=0.006), H$. tenuis $\left(F_{3,9}=4.70, P=0.031\right)$, and buprestids $\left(F_{3,9}=5.51, P=0.020\right)$. For $P$. picivorus $\left(F_{3,9}=5.98, P=0.016\right)$, only traps in the high severity burn plots caught significantly more than the controls, while treatment discrimination by $H$. salebrosus merely approached significance $\left(F_{3,9}=3.07, P=0.083\right)$. Catches of all five taxa during the first year post-burn exhibited a significant, positive correlation with fuel consumption (Table 3). The Spearman's rank order correlation coefficient for these relationships ranged between 0.604 and 0.704 . No significant correlations between insect capture and fuel consumption were observed for any taxon during the second year postburn. The flight period for all five responding taxa was largely confined to April-June, and trap catches in the first year post-burn were typically higher than the second (Fig. 3a-e).

Cerambycid borers did not exhibit a significant response to treatment (Tables 2 and 3), however, they resembled the responding taxa discussed above in that their trap captures were concentrated in the spring months and occurred in consistently greater numbers in the first year post-burn than the second (Fig. 3f).

Trap captures of the bark beetles D. terebrans and $I$. grandicollis were not strongly influenced by burn treatment during either the first or second year post-burn

Table 2

Mean numbers $( \pm \text { S.E. })^{\mathrm{a}}$ of insects captured per trap per week during the first and second years following prescribed burning at three different levels of fire severity

\begin{tabular}{|c|c|c|c|c|c|c|c|c|}
\hline \multirow[t]{3}{*}{ Insect taxon } & \multicolumn{8}{|c|}{ Burn severity } \\
\hline & \multicolumn{4}{|c|}{ First year post-burn ${ }^{\mathrm{b}}$} & \multicolumn{4}{|c|}{ Second year post-burn ${ }^{c}$} \\
\hline & Unburned & Low & Medium & High & Unburned & Low & Medium & High \\
\hline \multicolumn{9}{|l|}{ Scolytidae } \\
\hline D. terebrans & $0.18 \pm 0.04$ & $0.19 \pm 0.03$ & $0.25 \pm 0.02$ & $0.29 \pm 0.09$ & $0.23 \pm 0.03$ & $0.32 \pm 0.07$ & $0.29 \pm 0.05$ & $0.37 \pm 0.08$ \\
\hline H. salebrosus & $1.42 \pm 0.24$ & $2.24 \pm 0.69$ & $3.99 \pm 1.46$ & $6.08 \pm 2.94$ & $1.03 \pm 0.57$ & $0.61 \pm 0.09$ & $1.02 \pm 0.37$ & $0.90 \pm 0.06$ \\
\hline H. tenuis & $0.20 \pm 0.04 \mathrm{a}$ & $0.79 \pm 0.38 \mathrm{ab}$ & $1.37 \pm 0.41 \mathrm{~b}$ & $1.24 \pm 0.66 \mathrm{~b}$ & $0.21 \pm 0.06$ & $0.16 \pm 0.02$ & $0.14 \pm 0.01$ & $0.19 \pm 0.02$ \\
\hline I. grandicollis & $1.21 \pm 0.22$ & $1.41 \pm 0.15$ & $1.16 \pm 0.12$ & $1.17 \pm 0.24$ & $2.06 \pm 0.52$ & $1.92 \pm 0.38$ & $1.76 \pm 0.24$ & $1.76 \pm 0.33$ \\
\hline X. pubescens & $14.94 \pm 2.88 \mathrm{a}$ & $22.75 \pm 4.76 \mathrm{ab}$ & $29.72 \pm 5.25 \mathrm{~b}$ & $45.99 \pm 15.30 \mathrm{~b}$ & $6.51 \pm 2.28$ & $6.32 \pm 1.43$ & $6.08 \pm 1.29$ & $8.26 \pm 1.19$ \\
\hline \multicolumn{9}{|l|}{ Curculionidae } \\
\hline$P$. picivorus & $0.13 \pm 0.01 \mathrm{a}$ & $0.12 \pm 0.04 \mathrm{a}$ & $0.23 \pm 0.03 \mathrm{ab}$ & $0.31 \pm 0.03 \mathrm{~b}$ & $0.16 \pm 0.04$ & $0.13 \pm 0.02$ & $0.11 \pm 0.03$ & $0.18 \pm 0.02$ \\
\hline Buprestidae & $0.08 \pm 0.01 \mathrm{a}$ & $0.11 \pm 0.02 \mathrm{ab}$ & $0.19 \pm 0.03 \mathrm{~b}$ & $0.19 \pm 0.04 \mathrm{~b}$ & $0.08 \pm 0.02$ & $0.07 \pm 0.01$ & $0.09 \pm 0.04$ & $0.08 \pm 0.02$ \\
\hline Cerambycidae & $0.11 \pm 0.02$ & $0.12 \pm 0.05$ & $0.16 \pm 0.03$ & $0.18 \pm 0.03$ & $0.06 \pm 0.02$ & $0.07 \pm 0.02$ & $0.08 \pm 0.02$ & $0.05 \pm 0.02$ \\
\hline
\end{tabular}

\footnotetext{
${ }^{a}$ Means followed by the same letter were not significantly different (SNK test, $\alpha=0.05$ ).

${ }^{\mathrm{b}}$ Traps collected on 13 March-30 September 1997.

${ }^{\mathrm{c}}$ Traps collected on 9 March-24 September 1998.
} 

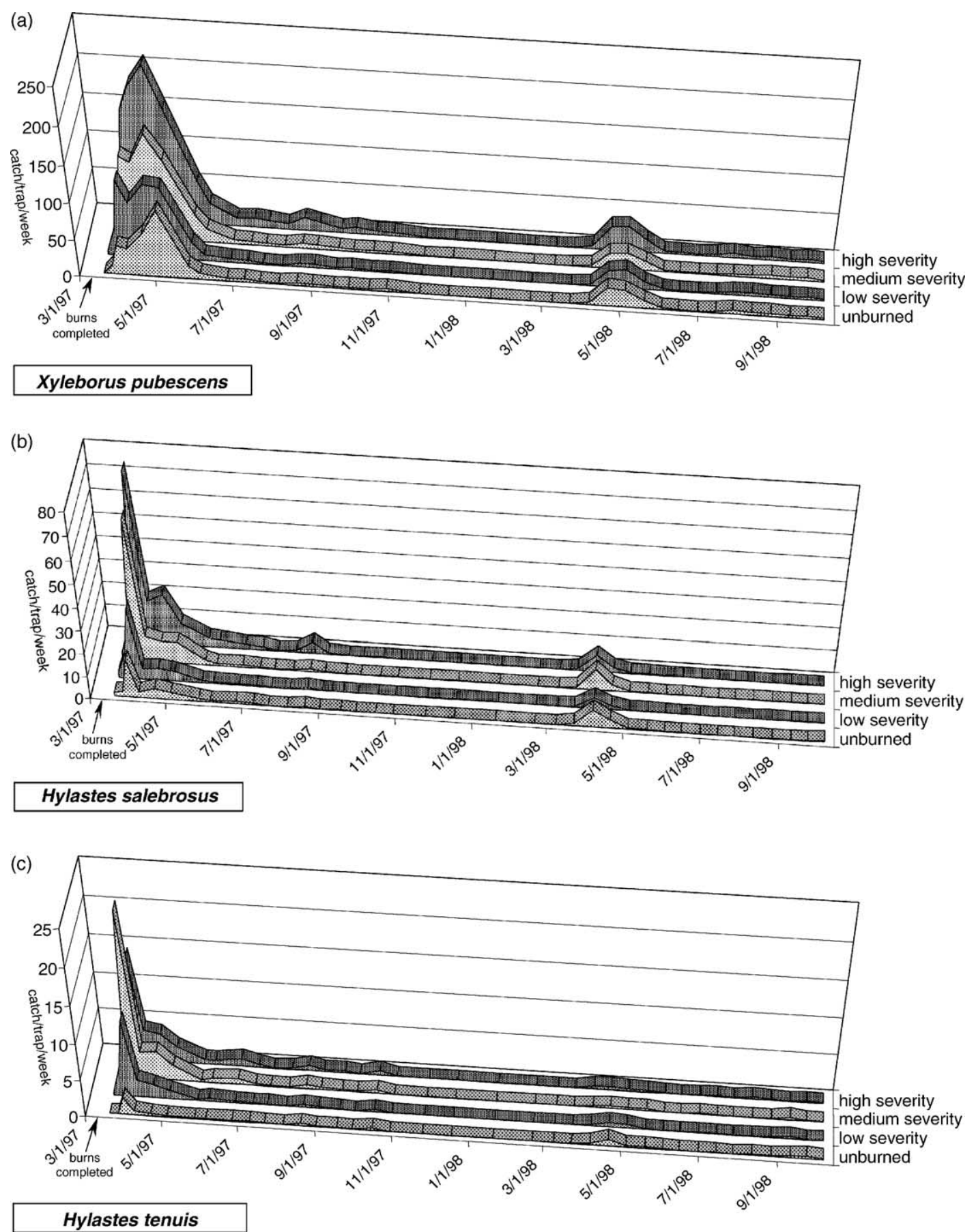

Fig. 3. Mean numbers of pine-infesting insects trapped per week in turpentine/ethanol-baited funnel traps in 2 ha plots of longleaf pine during the first 20 months following prescribed burning treatments. Plots were burned at one of the three different severities or were left unburned. Insect taxa trapped in significant numbers included the ambrosia beetle X. pubescens (a), the root beetles H. salebrosus (b) and H. tenuis (c), the reproduction weevil P. picivorus (d), wood borers in the families Buprestidae (e) and Cerambycidae (f), the black turpentine beetle $D$. terebrans $(\mathrm{g})$, and the southern pine engraver I. grandicollis $(\mathrm{h})$. 

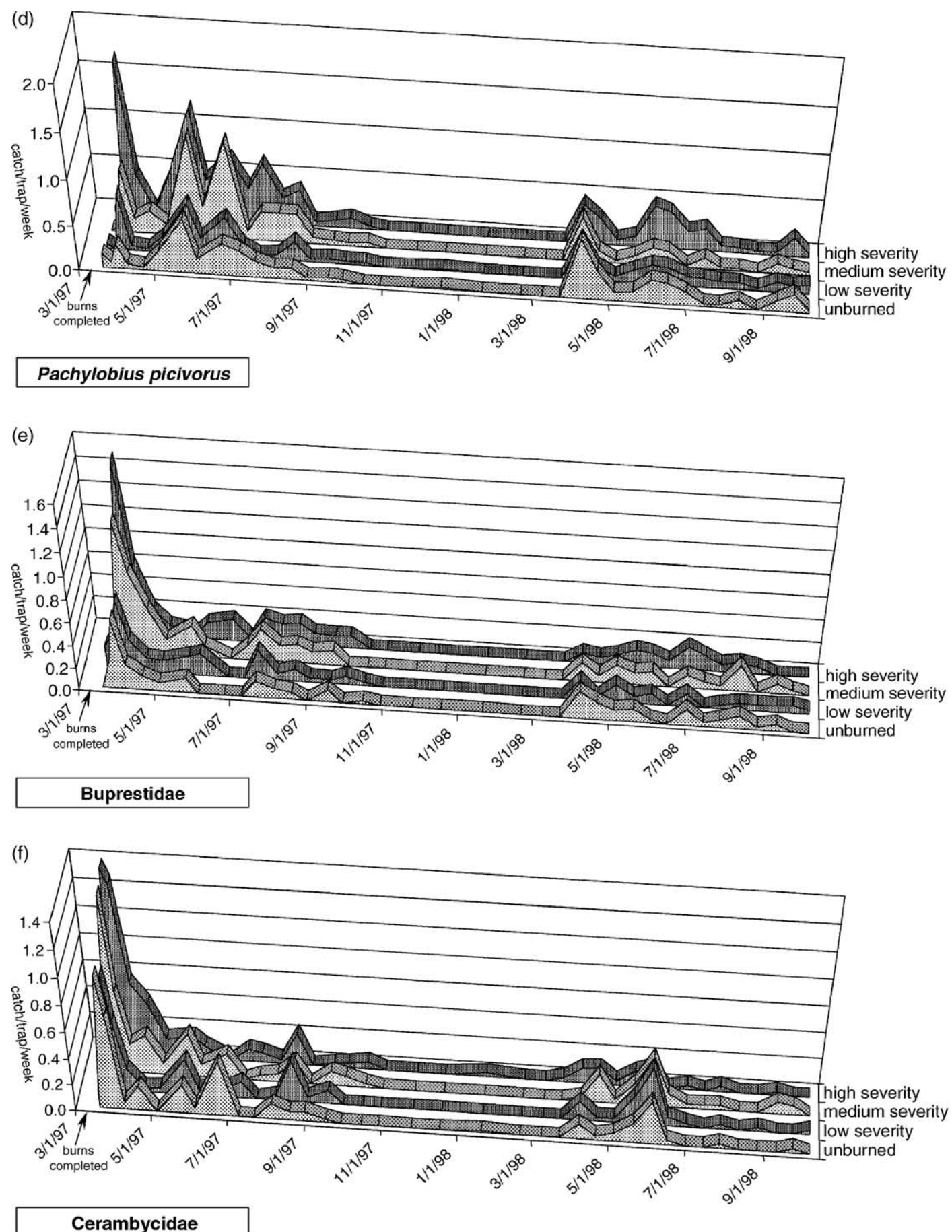

Fig. 3. (Continued) 


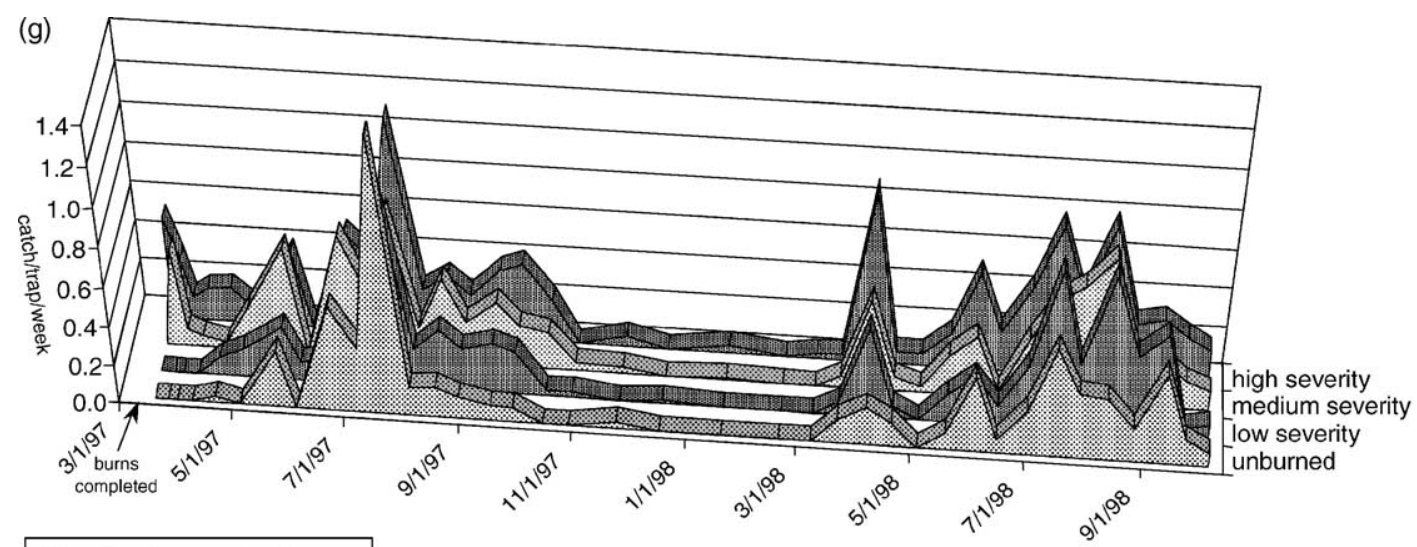

Dendroctonus terebrans

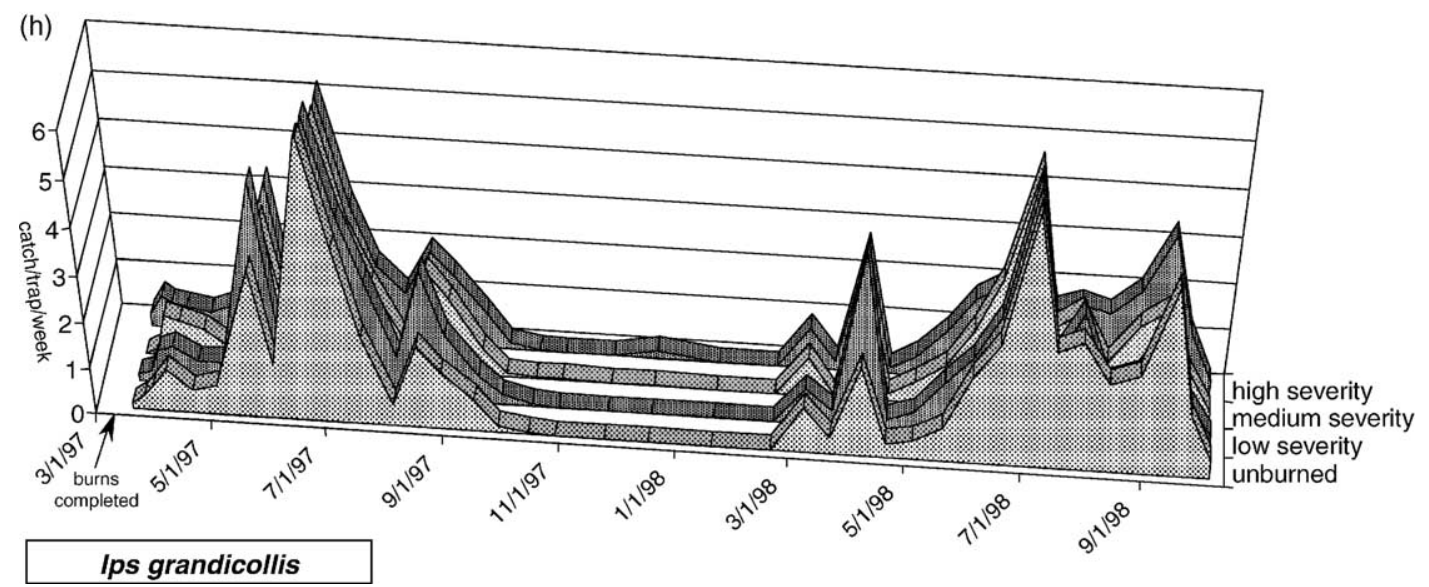

Fig. 3. (Continued).

$\left(F_{3,9}=0.13-1.60, P=0.26-0.94\right.$, Table 2$)$. Likewise, no significant correlations between fuel consumption and trap captures were observed for these species during either the first or second year post-burn (Table 3). The flight period for both species extended from March to October, and captures in the second year post-burn were typically higher than in the first (Fig. 3g and $\mathrm{h}$ ).

\section{Discussion}

Fire's role in tree mortality. Relatively low-intensity prescribed fires caused significant mortality to mature longleaf pines, and the amount of this mortality was directly correlated with soil heating and the consumption of surface fuels. Longleaf mortality following prescribed fire is not uncommon (Boyer, 1983, 1990). However, post-fire mortality in our study was somewhat atypical in that most occurred 2 and 3 years after the burns and very little occurred in the first year. Trees receiving lethal levels of heat injury commonly die within a year, the period in which the bulk of mortality typically occurs following wildfires (Hare, 1961; Dixon et al., 1984; Wade and Johansen, 1986; Rasmussen et al., 1996; Hanula et al., 2002). According to published criteria for predicting post-fire mortality of southern pines on the basis of crown scorch and bole char height, mortality in our plots should have been light or non-existent (Ferguson, 1955; Mann and Gunter, 1960; Storey and Merkel, 1960; Wade and Ward, 
Table 3

Spearman's rank order correlation between dry weight of fuel consumed during prescribed burns and insect trap catch during the first and second years following burns

\begin{tabular}{|c|c|c|c|c|}
\hline \multirow[t]{2}{*}{ Insect taxon } & \multicolumn{2}{|l|}{$\begin{array}{l}\text { First year } \\
\text { post-burn }^{a}\end{array}$} & \multicolumn{2}{|l|}{$\begin{array}{l}\text { Second year } \\
\text { post-burn }^{\text {b }}\end{array}$} \\
\hline & $\begin{array}{l}\text { Correlation } \\
\text { coefficient }\end{array}$ & $P$-value & $\begin{array}{l}\text { Correlation } \\
\text { coefficient }\end{array}$ & $P$-value \\
\hline \multicolumn{5}{|l|}{ Scolytidae } \\
\hline D. terebrans & 0.329 & 0.207 & 0.484 & 0.055 \\
\hline H. salebrosus & 0.604 & $0.013^{\mathrm{c}}$ & 0.484 & 0.055 \\
\hline H. tenuis & 0.687 & $0.003^{\mathrm{c}}$ & 0.232 & 0.378 \\
\hline I. grandicollis & -0.040 & 0.874 & -0.095 & 0.721 \\
\hline$X$. pubescens & 0.625 & $0.009^{\mathrm{c}}$ & 0.324 & 0.215 \\
\hline \multicolumn{5}{|l|}{ Curculionidae } \\
\hline P. picivorus & 0.640 & $0.007^{\mathrm{c}}$ & 0.146 & 0.578 \\
\hline Buprestidae & 0.704 & $0.002^{\mathrm{c}}$ & -0.046 & 0.856 \\
\hline Cerambycidae & 0.485 & 0.055 & -0.140 & 0.594 \\
\hline
\end{tabular}

1975). However, temperatures recorded at the surface of the mineral soil in the high severity burn treatments exceeded those necessary to kill fine roots (Hare, 1961; Ursic, 1961), and histological examinations revealed extensive heat damage to fine surface roots in these sites (Otrosina et al., 2002). Extensive pine mortality following ground fires has been attributed to destruction of feeder roots in the duff or near the soil surface (Wade and Johansen, 1986; Swezy and Agee, 1990). Heat-damage to fine roots also might have indirectly caused mortality in our sites by weakening trees and rendering them more susceptible to biotic mortality agents.

The precise role of bark beetles in causing tree mortality within our burned plots is uncertain. Evidence of infestation by D. terebrans and/or Ips spp. beetles was present in nearly all trees with fading or dead crowns, however, these species are known to attack and reproduce in trees killed or severely weakened by other agents, and, in the case of D. terebrans, can infest trees without killing them (Thatcher, 1960; Coulson and Witter, 1984). These beetles can be primary mortality agents only when their densities are adequately high. Following wildfires, bark beetles can sometimes accumulate in severely injured or fire-killed trees, resulting in populations capable of killing adjacent, healthy trees (Furniss, 1965; Rasmussen et al., 1996). However, the slow accumulation of mortality within our burn plots and its rarity in the first year post-burn did not suggest such a scenario.

The fire-associated mortality may have been related to a high incidence of root disease in the study plots. The experiment site had a high hazard rating for Heterobasidion annosum (Fr.) root rot (Alexander and Anderson, 1985), and a high percentage of longleaf pine roots within the experimental plots were infected with $H$. annosum as well as various Leptographium spp. fungi of uncertain pathogenicity (Otrosina et al., 2002). Mortality in the burned plots typically occurred in gradually expanding pockets, a common sign of both $H$. annosum infection and decline syndromes associated with some Leptographium spp. (Robbins, 1984; Cobb, 1988; Klepzig et al., 1991; Otrosina et al., 1999). Root diseases are known to increase tree susceptibility to bark beetle infestation (Cobb et al., 1974; Alexander et al., 1980; Goheen and Cobb, 1980; Livingston et al., 1983). While the relationship specifically between prescribed burning and the pathogenesis of $H$. annosum and other root fungi is largely unstudied, a variety of forest disturbances associated with root injury are known to increase infection by root diseases (Harrington et al., 1983; Robbins, 1984; Cobb, 1988). Root fungi could have opportunistically infected trees in the higher-severity burn plots through damaged roots and other fireproduced injuries (Geiszler et al., 1980, 1984; Gara et al., 1986). It is also possible that established, latent infections were able to rapidly spread within and among host trees because of fire-induced stress (Otrosina et al., 2002). Significantly, the typical interval between stand disturbance/tree injury and the appearance $H$. annosum symptoms and mortality (i.e., 1-2 years) coincided with the delay observed in the present study between burning and the bulk of the observed mortality (Hodges, 1970; Robbins, 1984). If mortality of longleaf pine following prescribed fire can be attributed in part to root disease, then the consequences of burning may be greatly influenced by local hazard conditions for specific pathogens.

Burn-induced attraction. Our data provide strong evidence that certain pine-infesting beetles are attracted to longleaf pine stands treated with prescribed fire and indicate that stand attractiveness 
increases with greater fire severity. Treatment discrimination, as reflected by trap catch, initially appeared (and often peaked) 2-3 weeks after burn completion. This interval would not have been adequate for an increase in the local population of these insects in firekilled or injured trees. The precise generation times for most of the attracted species is not known, however, $P$. picivorus require 2-3 months to complete one generation (Speers, 1974; Godbee and Franklin, 1976), Hylastes spp. can require 2 months to 1 year (ZethnerMoller and Rudinsky, 1967; Milligan, 1978; Klepzig, 1994), Xyleborus spp. typically require 3-11 weeks (Solomon, 1995), and buprestid generation times are typically several months to several years (Baker, 1972; Solomon, 1995). Hence, the greater numbers of these insects trapped in the burned plots in the first week following burning were not the products of greater reproduction within the plots themselves, rather, they must have immigrated from the surrounding forest.

None of the beetle taxa attracted to the burns are generally considered important pests of mature pines. All are obligate tree scavengers and are normally restricted to breeding in hosts that are severely weakened or dying (Baker, 1972; Coulson and Witter, 1984). However, they differ from one another in specializing on different host tissues. P. picivorus, and Hylastes spp. reproduce in the roots and root collar, the ambrosia beetle $X$. pubescens infests the sapwood of the trunk and root collar, while buprestids infest both the phloem and wood of the trunk (Blackman, 1941; Franklin and Taylor, 1970; Baker, 1972; Wood, 1982). Attraction to burned areas is a behavior which likely benefits these beetles by permitting the rapid location and exploitation of host resources rendered susceptible by fire injury. Evidence of such rapid exploitation of fire-generated resources was present in the high severity burn plots. During the first week months post-burn, dissection of young pine regeneration killed or seriously injured by the burns revealed infestation by $H$. tenuis, $P$. picivorus, and $X$. pubescens.

The absence of significant tree mortality during the period when these beetles were attracted into the burns (i.e., the first year post-burn) supports the contention that these secondary beetles inflicted no immediately lethal damage to mature trees. However, some of the burn-attracted species trapped in or near the burned stands, particularly Hylastes spp. and P. picivorus, were found to be carrying spores of possibly pathogenic
Leptographium fungi (B.T. Sullivan and W.J. Otrosina, unpublished data). Hylastes beetles and root-infesting weevils are known to vector several species of Leptographium fungi and have been implicated in the proliferation of some disease syndromes of pines (Lewis and Alexander, 1986; Witcosky et al., 1986; Harrington, 1988; Nevill and Alexander, 1992; Klepzig et al., 1995). In longleaf stands near our study site, increasing degrees of crown thinning and discoloration were associated with greater prevalence of Leptographium spp. infection and beetle damage to roots (Otrosina et al., 1999). The authors observed resinosis in association with both fungal infection and beetle galleries in roots of symptomatic trees, and they suggested that these organisms could be contributing directly to tree decline.

Our trapping experiment did not indicate that prescribed fires attract aggressive, potentially tree-killing bark beetles into stands. Two significant pests of pines in the South, the bark beetles D. terebrans and $I$. grandicollis, were not attracted to the burned plots. These relatively aggressive beetles can attack and breed in the phloem of healthy trees in addition to attacking and reproducing in dying or severely weakened trees (Thatcher, 1960; Smith and Lee, 1972; Connor and Wilkinson, 1983). In contrast, similarly aggressive bark beetle species, I. pini (Say) and D. valens LeConte, are attracted to stands of red and ponderosa pine, respectively, following prescribed burns (Chris Niwa, personal communication; Santoro et al., 2001).

It is possible that some potentially important coniferophagous beetles were attracted into our burn plots but not detected with our traps, since both the particular bait and style of trap used in our study likely influenced the range of species captured. For example, two economically important bark beetles, I. avulsus and I. calligraphus, were trapped in insignificant numbers despite their apparent abundance in freshly killed trees. Neither of these species is attracted to ethanol and turpentine (Smith et al., 1993). One should not assume that our trapping results reflected the true relative proportions among different insect taxa in the stands.

A variety of cues may have mediated insect attraction to the burn plots. Physical and chemical products of combustion, such as heat, smoke, and the odors of charred plant material are attractive to some 
fire-associated forest insects (Kessel, 1960; Evans, 1964; Schmitz et al., 1997; Suckling et al., 2001). However, these cues would generally have reached their maximum intensity during or immediately after the burns, and thus would have preceded peak attraction for all insects by several weeks. Alternatively, volatile chemicals emitted by pines and other vegetation in response to fire-related heat stress and damage might have been the attractants. The volatile terpenoid components of resin, either alone or with ethanol, are known attractants for three beetle species, $H$. salebrosus, $P$. picivorus, and $X$. pubescens, that responded to the burned plots (Phillips et al., 1988; Phillips, 1990; Hunt and Raffa, 1989). The more severely charred pine boles exuded resin droplets through the bark, and open bark wounds from thinning operations or fusiform rust (Cronartium quercuum $\mathrm{f}$. sp. fusiforme) infections ignited, resulting in resin flows that persisted for several weeks. In addition, ethanol is produced by plants in response to stress (Kimmerer and Kozlowski, 1982) and was likely released by heat-injured trees and other vegetation. Ethanol concentrations in ponderosa pine stems following wildfire are directly related to the severity of crown damage (Kelsey and Gladwin, 2002). However, two beetle species known to be attracted to turpentine and/or ethanol, D. terebrans, and I. grandicollis (Fatzinger, 1985; Fatzinger et al., 1987; Chenier and Philogene, 1989), showed no preference for the burned plots.

Our study demonstrated that dormant-season heading fires performed under moisture conditions that prevent fire penetration into the duff layers can permit the near complete elimination of litter fuels while enhancing the long-term survival of longleaf pines. The reproducibility of our findings will very likely depend upon both site characteristics and burn season, and further research is needed to determine whether burn regimes that minimize longleaf mortality adequately address other burn objectives, such as elimination of hardwoods.

\section{Acknowledgements}

We thank the members of the fire crew at the Forest Service-Savannah River, especially Ron Shurney, Dan Shea, and Eric Scholl, for their outstanding efforts in conducting the burns and collecting fuel and other burn-related data. We also thank John Blake for initiating, overseeing, and coordinating this project for the US Forest Service. Tom Atkinson graciously provided identifications of Scolytids. Technical assistance was provided by Richard Garland, Elizabeth Skillen, Jay Smith, Katja Seltmann, Melissa McNeely, and others. Jim Hanula, Chris Niwa, and Kier Klepzig provided helpful comments on the original manuscript. Funding was provided by the Department of Energy-Savannah River Operations Office through the US Forest Service Savannah River under Interagency Agreement DE-IA09-00SR22188.

\section{References}

Alexander, S.A., Anderson, R.L., 1985. How to identify and control annosus root rot in the south. USDA Forest Service Southern Region Forestry Bulletin R8-FB/P 19, Atlanta, GA.

Alexander, S.A., Skelly, J.M., Webb, R.S., Bardinelli, T.R., Bradford, B., 1980. Association of Heterobasidion assosum and the southern pine beetle on loblolly pine. Phytopathology 70, 510-513.

Baker, W.L., 1972. Eastern Forest Insects. USDA Forest Service Miscellaneous Publication No. 1175, 642 pp.

Barnett, J.P., 1992. The South's longleaf pine: it can rise again! Forests and People 42, 14-17.

Barnett, J.P., 1999. Longleaf pine ecosystem restoration: the role of fire. J. Sustain. For. 9, 89-96.

Blackman, M.W., 1941. Bark Beetles of the Genus Hylastes Erichson in North America. USDA Miscellaneous Publication No. 417, Washington, DC, 27 pp.

Borror, D.J., Triplehorn, C.A., Johnson, N.F., 1989. An Introduction to the Study of Insects, 6th ed. Harcourt Brace Jovanovich College Publishers, New York, 875 pp.

Boyer, W.D., 1983. Growth of longleaf pine as affected by biennial burns plus chemical or mechanical treatments for competition control. In: Jones, E.P. (Ed.), Proceedings of the Second Biennial Southern Silvicultural Research Conference. USDA Forest Service Southeastern Forest Experiment Station General Technical Report SE-24, pp. 62-65.

Boyer, W.D., 1990. Growing-season burns for control of hardwoods in longleaf pine stands. USDA Forest Service Southern Research Station Research Paper SO-256, New Orleans, LA, 7 pp.

Bruce, D., 1947. Thrity-two years of annual burning in longleaf pine. J. For. 45, 809-814.

Burns, R.M., Honkala, B.H., 1990. Silvics of North America, vol. 1, Conifers. USDA Forest Service Agriculture Handbook 654. Washington DC, pp. 405-412.

Chenier, J.V.R., Philogene, B.J.R., 1989. Field responses of certain forest Coleoptera to conifer monoterpenes and ethanol. J. Chem. Ecol. 15, 1729-1745. 
Cobb Jr., F.W., 1988. Leptographium wageneri, cause of blackstain root disease: a review of is discovery, occurrence and biology with emphasis on pinyon and ponderosa pine. In: Harrington, T.C., Cobb Jr., F.W. (Eds.), Leptographium Root Diseases on Conifers. APS Press, St. Paul, MN, pp. 41-62.

Cobb Jr., F.W., Parmeter Jr., J.R., Wood, D.L., Stark, R.W., 1974. Root pathogens as agents predisposing ponderosa pine and white fir to bark beetles. In: Kuhlman, E.G. (Ed.), Proceedings of the fourth International Conference on Fomes annosus. IUFRO Section 24: Forest Protection, pp. 8-15.

Connor, C.D., Wilkinson, R.C., 1983. Ips bark beetles in the South. USDA Forest Service Forest Insect and Disease Leaflet 129, 7 pp.

Cooper, R.W., 1971. Current use and place of prescribed burning. In: Proceedings of the Prescribed Burning Symposium. USDA Forest Service Southeastern Forest Experiment Station, Asheville, NC, pp. 21-27.

Cooper, R.W., 1975. Prescribed burning. J. For. 73, 776-780.

Coulson, R.N., Witter, J.A., 1984. Forest Entomology, 1st ed. Wiley, New York, 669 pp.

Croker Jr., T.C., Boyer, W.D., 1975. Regenerating longleaf pine naturally. USDA Forest Service Southern Forest Experiment Station Research Paper SO-105, 21 pp.

Davis, P., 1959. Forest Fire Control and Use. McGraw-Hill, New York.

Dixon, W.N., Corneil, J.A., Wilkinson, R.C., Foltz, J.L., 1984. Using stem char to predict mortality and insect infestation of fire-damaged slash pines. South. J. Appl. For. 8, 85-88.

Evans, W.G., 1964. Infra-red receptors in Melanophila acuminata DeGeer. Nature 202, 211.

Fahnestock, G.R., Hare, R.C., 1964. Heating of tree trunks in surface fires. J. For. 62, 799-805.

Fatzinger, C.W., 1985. Attraction of the black turpentine beetle (Coleoptera: Scolytidae) and other forest Coleoptera to turpentine-baited traps. Environ. Entomol. 14, 768-775.

Fatzinger, C.W., Siegfried, B.D., Wilkinson, R.C., Nation, J.L., 1987. Trans-verbenol, turpentine, and ethanol as trap baits for the black turpentine beetle, Dendroctonus terebrans, and other forest coleoptera in North Florida. J. Entomol. Sci. 22, 201-209.

Ferguson, E.R., 1955. Fire-scorched trees-will they live or die? In: Proceedings of the Fourth Annual Forestry Symposium. Louisiana State University, Baton Rouge, LA, pp. 102-113.

Fernandez, M.M.F., Costas, J.M.S., 1999. Susceptibility of firedamaged trees (Pinus pinaster and Pinus nigra) to attacks by Ips sexdentatus and Tomicus piniperda (Coleoptera: Scolytidae). Entomologia Generalis 24, 105-114.

Franklin, R.T., Taylor Jr., J.W., 1970. Biology of Pachylobius picivorus (Coleoptera: Curculionidae) in the Georgia piedmont. Can. Entomol. 102, 962-968.

Furniss, M.M., 1965. Susceptibility of fire-injured douglas-fir to bark beetle attack in southern Idaho. J. For. 63, 8-11.

Gara, R.I., Agee, J.K., Littke, W.R., Geiszler, D.R., 1986. Fire wounds and beetle scars. J. For. 84, 47-50.

Geiszler, D.R., Gara, R.I., Driver, C.H., Gallucci, V.F., Martin, R.E., 1980. Fire, fungi, and beetle influences on a lodgepole pine ecosystem of south-central Oregon. Oecologia 46, 239-243.
Geiszler, D.R., Gara, R.I., Littke, W.R., 1984. Bark beetle infestations of lodgepole pine following a fire in south central Oregon. J. Appl. Entomol. 98, 389-394.

Godbee, J.F., Franklin, R.T., 1976. Attraction, attack patterns and seasonal activity of the black turpentine beetle. Ann. Entomol. Soc. Am. 69, 653-655.

Goheen, D.J., Cobb Jr., F.W., 1980. Infestation of Ceratocystis wageneri-infected ponderosa pines by bark beetles (Coleoptera: Scolytidae) in the central Sierra Nevada. Can. Entomol. 112, 725-730.

Hanula, J.L., Meeker, J.R., Miller, D.R., Barnard, E.L., 2002. Association of wildfire with tree health and numbers of pine bark beetles, reproduction weevils and their associates in Florida. For. Ecol. Manage. 170, 233-247.

Hare, R.C., 1961. Heat effects on living plants. USDA Forest Service Southern Forest Experiment Station Occasional Paper 183, New Orleans, LA, pp. 1-32.

Harrington, T.C., 1988. Leptographium species, their distribution, hosts and insect vectors. In: Harrington, T.C., Cobb Jr., F.W. (Eds.), Leptographium Root Diseases on Conifers. APS Press, St. Paul, MN, pp. 1-39.

Harrington, T.C., Reinhart, C., Thornburgh, D.A., Cobb Jr., F.W., 1983. Association of black-stain root disease with precommercial thinning of douglas-fir. For. Sci. 29, 12-14.

Haywood, J.D., Harris, F.L., Grelen, H.E., Pearson, H.A., 2001. Vegetative response to 37 years of seasonal burning on a Louisiana longleaf pine site. South. J. Appl. For. 25, 122-130.

Hodges, C.S., 1970. Fomes annosus in the Southern United States. In: Toussoun, T.A., Bega, R.V., Nelson, P.E. (Eds.), Root Diseases and Soil-Borne Pathogens. University of California Press, Berkeley, CA, pp. 153-155.

Horton, T., 1998. Longleaf redux. Am. For. 104, 16-21.

Hunt, D.W.A., Raffa, K.F., 1989. Attraction of Hylobius radicis and Pachylobius picivorus (Coleoptera: Curculionidae) to ethanol and turpentine in pitfall traps. Environ. Entomol. 18, 351-355.

Johnson, R., Gjerstad, D., 1998. Landscape-scale restoration of the longleaf pine ecosystem. Restor. Manage. Notes 16, 41-45.

Kelsey, R.G., Gladwin, J., 2002. Ethanol production in fire damaged ponderosa pine and its potential influence on beetle host selection. In: Abstracts from the 87th Annual Meeting of the Ecological Society of America, pp. 372-373.

Kessel, E.L., 1960. The response of Microsania and Hormopeza to smoke. Pan-Pac. Entomol. 36, 67-68.

Kimmerer, T.W., Kozlowski, T.T., 1982. Ethylene, ethane, acetaldehyde, and ethanol production by plants under stress. Plant Physiol. 69, 840-847.

Klepzig, K.D., 1994. Interactions of stress, plant chemical defenses and subcortical insect-fungal complexes in red pine decline. Ph.D. Dissertation. University of Wisconsin.

Klepzig, K.D., Raffa, K.F., Smalley, E.B., 1991. Association of an insect-fungal complex with red pine decline in Wisconsin. For. Sci. 37, 1119-1139.

Klepzig, K.D., Smalley, E.B., Raffa, K.F., 1995. Dendroctonus valens and Hylastes porculus (Coleoptera: Scolytidae): vectors of pathogenic fungi (Ophiostomatales) associated with red pine decline disease. Great Lakes Entomol. 28, 81-87. 
Langdon, G.O., 1971. Effects of prescribed burning on timber species in the southeastern coastal plain. In: Proceedings of the Prescribed Burning Symposium. USDA Forest Service Southeastern Forest Experiment Station, Asheville, NC, pp. 34-44.

Lewis, K.J., Alexander, S.A., 1986. Insects associated with the transmission of Verticicladiella procera. Can. J. For. Res. 16, 1330-1333.

Livingston, W.H., Mangini, A.C., Kinzer, H.G., Mielke, M.E., 1983. Association of root diseases and bark beetles (Coleoptera: Scolytidae) with Pinus ponderosa in New Mexico. Plant Dis. 67, 674-676.

Mann Jr., W.F., Gunter, E.R., 1960. The odds for a fire-damaged pine to die. USDA Forest Service Southern Forest Experiment Station Southern Forestry Note 126, New Orleans, LA, 2 pp.

McCullough, D.G., Werner, R.A., Neumann, D., 1998. Fire and insects in northern and boreal forest ecosystems of North America. Annu. Rev. Entomol. 43, 107-127.

Milligan, R.H., 1978. Hylastes ater (Paykull) (Coleoptera: Scolytidae). Black pine bark beetle. New Zealand Forest Service Forest and Timber Insects in New Zealand No. 29.

Nevill, R.J., Alexander, S.A., 1992. Transmission of Leptographium procerum to eastern white pine by Hylobius pales and Pissodes nemorensis (Coleoptera: Curculionidae). Plant Dis. 76, 307-310.

Noss, R.F., 1989. Longleaf pine and wiregrass: keystone components of an endangered ecosystem. Nat. Areas J. 9, 211-213.

Otrosina, W.J., Bannwart, D., Roncadori, R.W., 1999. Rootinfecting fungi associated with a decline of longleaf pine in the southeastern United States. Plant Soil 217, 145-150.

Otrosina, W.J., Walkinshaw, C.H., Zarnoch, S.J., Sung, S.J., Sullivan, B.T., 2002. Root disease, longleaf pine mortality, and prescribed burning. In: Outcalt, K.W. (Ed.), Proceedings of the 11th Biennial Southern Silvicultural Research Conference. USDA Forest Service Southern Research Station General Technical Report SRS-48, pp. 551-557.

Phillips, T.W., 1990. Responses of Hylastes salebrosus to turpentine, ethanol, and pheromones of Dendroctonus (Coleoptera: Scolytidae). Fla. Entomol. 73, 286-292.

Phillips, T.W., Wilkening, A.J., Atkinson, T.H., Nation, J.L., Wilkinson, R.C., Foltz, J.L., 1988. Synergism of turpentine and ethanol as attractants for certain pine-infesting beetles (Coleoptera). Environ. Entomol. 17, 456-462.

Rasmussen, L.A., Amman, G.D., Vandygriff, J.C., Oakes, R.D., Munson, A.S., Gibson, K.E., 1996. Bark beetle and wood borer infestation in the greater Yellowstone area during four postfire years. USDA Forest Service Intermountain Research Station Research Paper INT-RP-487, Ogden, UT, pp. 1-10.

Robbins, K., 1984. Annosus root rot in eastern conifers. USDA Forest Service Forest Insect and Disease Leaflet No. 76.

Santoro, A.E., Lombardero, M.J., Ayres, M.P., Ruel, J.J., 2001. Interactions between fire and bark beetles in an old growth pine forest. For. Ecol. Manage. 144, 245-254.

Schmitz, H., Bleckmann, H., Mürtz, M., 1997. Infrared detection in a beetle. Nature 386, 773-774.
Scholl, E.R., Waldrop, T.A., 1999. Photos for estimating fuel loadings before and after prescribed burning in the upper coastal plain of the Southeast. USDA Forest Service Southern Research Station General Technical Report SRS-26, Asheville, NC, 25 pp.

Smith, R.H., Lee, R.E.I., 1972. Black turpentine beetle. USDA Forest Service Forest Pest Leaflet 12, pp. 1-8.

Smith, M.T., Salom, S.M., Payne, T.L., 1993. The southern pine bark beetle guild: an historical review of the research on the semiochemical-based communication system of the five principal species. Virginia Agricultural Experiment Station Bulletin 93-4, Blacksburg, VA, 106 pp.

Solomon, J.D., 1995. Guide to Insect Borers of North American Broadleaf Trees and Shrubs. USDA Forest Service Agricultural Handbook 706, Washington, DC, 735 pp.

Speers, C.F., 1974. Pales and pitcheating weevils: development in relation to time pines are cut in the southeast. USDA Forest Service Southeastern Forest Experiment Station Research Note SE-207, Asheville, NC, 7 pp.

SPSS, 1997. SigmaStat ${ }^{\circledR} 2.0$ for Windows ${ }^{\circledR}$ : User's Manual. SPSS Inc., Chicago, IL.

Storey, T.G., Merkel, E.P., 1960. Mortality in a longleaf-slash pine stand following a winter wildfire. J. For. 58, 206-210.

Suckling, D.M., Gibb, A.R., Daly, J.M., Chen, D., Brockerhoff, E.G., 2001. Behavioral and electrophysiological responses of Arhopalus tristis to burnt pine and other stimuli. J. Chem. Ecol. 27, 1091-1104.

Swezy, D.M., Agee, J.K., 1990. Prescribed-fire effects on fine-root and tree mortality in old-growth ponderosa pine. Can. J. For. Res. 21, 626-634.

Thatcher, R.C., 1960. Bark beetles affecting southern pines: a review of current knowledge. USDA Forest Service Southern Forest Experiment Station Occasional Paper 180, 25 pp.

Ursic, S.J., 1961. Lethal root temperatures of 1-0 loblolly pine seedlings. USDA Forest Service Southern Forest Experiment Station Tree Planters' Notes No. 47, Oxford, MS, pp. 25-47.

Wade, D.D., Johansen, R.W., 1986. Effects of fire on southern pine: observations and recommendations. USDA Forest Service Southeastern Forest Experiment Station General Technical Report SE-41, Asheville, NC, 14 pp.

Wade, D.D., Ward, D.E., 1975. Management decisions in severely damaged stands. J. For. 73, 573-577.

Witcosky, J.J., Schowalter, T.D., Hansen, E.M., 1986. Hylastes nigrinus (Coleoptera: Scolytidae), Pissodes fasciatus, and Steremnius carinatus (Coleoptera: Curculionidae) as vectors of black-stain root disease of douglas fir. Environ. Entomol. 15, 1090-1095.

Wood, S.L., 1982. The bark and ambrosia beetles of North and Central America (Coleoptera: Scolytidae), a taxonomic monograph. Great Basin Naturalist Memoirs 6, 1359 pp.

Wright, H.A., Bailey, A.W., 1982. Fire Ecology. Wiley, New York.

Zethner-Moller, O., Rudinsky, J.A., 1967. On the biology of Hylastes nigrinus (Coleoptera: Scolytide) in western Oregon. Can. Entomol. 99, 897-911. 